\title{
TUJUAN DAN MANFAAT PERENCANAAN KEPERAWATAN GUNA MENINGKATKAN KESEHATAN PASIEN
}

\author{
Nuraini sihite \\ Email: nurainisihite4@gmail.com
}

\section{Latar Belakang}

Perencanaan asuhan keperawatan merupakan kunci dari continuity of care. Dokumentasi perencanaan asuhan keperawatan yang tidak saling berkesinambungan dalam rekam medis berdampak pada kualitas asuhan pasien.

Perawat memiliki tugas untuk memberikan asuhan keperawatan (askep), perencanaan pelayanan kesehatan merupakan sebuah proses untuk merumuskan masalah masalah kesehatan yang berkembang di masyarakat menentukan kebutuhan dan sumber daya yang tersedia, menetapkan tujuan program yang paling pokok dan menyusun langkah-langkah praktis untuk mencapai tujuan yang telah ditetapkan titik perencanaan merupakan inti kegiatan manajemen karena semua kegiatan manajemen diatur dan diarahkan oleh perencanaan tersebut.

sistem pelayanan kesehatan adalah satu kesatuan susunan yang terdiri dari berbagai elemen kesehatan yang berkaitan secara teratur dengan tujuan mempromosikan dan memulihkan atau menjaga kesehatan perorangan, keluarga, dan kelompok masyarakat. Keberhasilan sistem pelayanan kesehatan tergantung dari berbagai komponen yang masuk dalam pelayanan kesehatan titik sistem terbentuk dari subsistem yang saling berhubungan dan saling mempengaruhi.

pelayanan keperawatan merupakan bagian dari pelayanan kesehatan yang meliputi pelayanan dasar dan rujukan sehingga meningkatkan derajat kesehatan titik pada tingkat pelayanan dasar dilakukan di lingkup Puskesmas dengan pendekatan asuhan Keperawatan keluarga dan komunitas yang berorientasi pada tugas keluarga dalam kesehatan,diantaranya adalah mengenal masalah kesehatan secara dini, mengambil keputusan, menanggulangi keadaan darurat,memberikan pelayanan dasar pada anggota keluarga yang sakit serta memodifikasi lingkungan. 
Tujuan dari perencanaan keperawatan adalah untuk membuat keputusan yang baik mengenai hal-hal yang perlu dilaksanakan dan cara melaksanakannya dengan perencanaan dapat disediakan arah yang perlu ditempuh dalam pencapaian tujuan titik perencanaan juga memungkinkan adanya kontrol yang efektif karena dengan perencanaan, pelaksanaan dapat menyusun standar yang dapat dijadikan petunjuk dalam menilai aktivitas.

\section{Metode}

Metode yang digunakan pada kajian ini adalah metode kualitatif yang memberikan penjelasan dengan menggunakan analisis pada referensi yang digunakan. Untuk mengumpulkan data-data dari beberapa jurnal dan e-book dari situs internet yang berhubungan dengan topik pembahasan yaitu tujuan dan manfaat perencanaan keperawatan guna meningkatkan kesehatan pasien. Karena keterbatasan waktu, cakupan luas dari topik, dan untuk lebih spesifik, maka dilakukan batasan waktu pada tahun publikasinya dengan waktu minimalnya delapan tahun terakhir yaitu dari tahun 2012 dengan mengambil referensi yang terkait dengan topik yang digunakan.

\section{Hasil}

Tahap pertama yang dilakukan dalam kajian ini adalah dengan melakukan pengumpulan data dengan studi dokumen, jurnal dan e-book tentang asuhan keperawatan yang dijadikan sebagai data dasar.

Perencanaan (intervensi) keperawatan adalah semua tindakan asuhan yang perawat lakukan atas nama klien. Tindakan ini merupakan termasuk intervensi yang diprakarsai oleh perawat, dokter, atau intervensi kolaboratif. Pelaksanaan (implementasi) adalah pengelolaan dan perwujudan dari rencana keperawatan yang telah disusun pada tahap perencanaan.

Pada proses perencanaan intervensi, perawat jarang mengalami kesulitan. Hal ini dikarenakan proses perencanaan sudah mengacu pada panduan yang sudah tersedia di tiap Rumah Sakit. Panduan tersebut berupa lembar intervensi keperawatan berdasarkan tiap diagnosa keperawatan yang telah ditentukan. Wijaya (2016) 
Idealnya, perencanaan asuhan keperawatan bersifat individualistik dan responsif terhadap kebutuhan unik pasien. Tujuannya adalah menyusun strategi untuk mengatasi hambatan atau masalah pasien. Perawat secara teratur meninjau kemajuan pasien dan merevisi rencana perawatan yang sesuai dengan kebutuhan pasien.

Perencanaan sebagai upaya memutuskan apa yang akan dilakukan, siapa yang melakukan, bagaimana, kapan dan dimana hal tersebut akan dilakukan. Perencanaan adalah suatu proses memulai dengan sasaran, batasan strategi, kebijakan dan rencana detail untuk mencapainya.

Tujuan penerapan proses keperawatan bagi profesionalitas keperawatan antara lain:

1. mempraktikkan metode pemecahan masalah dalam praktek keperawatan.

2. Menggunakan standar praktik keperawatan.

3. Memperoleh metode yang baku, rasional dan sistematis.

4.memperoleh hasil asuhan Keperawatan dengan efektivitas yang tinggi.

Proses keperawatan merupakan metode sistematis untuk menilai, mendiagnosis, merencanakan, melaksanakan dan evaluasi keadaan pasien dalam keadaan sehat maupun sakit sehingga menjadi dasar pemecahaan secara ilmiah, dan menjadi dasar dalam praktik keperawatan.

\section{Pembahasan}

Asuhan keperawatan adalah kerangka kerja dan struktur organisasi yang kreatif untuk memberikan pelayanan keperawaan, namun asuhan keperawatan juga cukup fleksibel untuk digunakan disemua lingkup keperwatan.

Pada hasil penelitian juga menggambarkan bahwa perawat pelaksana telah melakukan asuhan asuhan keperawatan pada tahap perencanaan/intervensi keperawatan dimana tujuannya berpusat pada pasien, dan hasil diperkirakan ditentukan dan intervensi keperawatan dipilih untuk mencapai tujuan. 
Perencanaan tenaga keperawatan pada level kepala ruangan meliputi orientasi tenaga keperawatan baru, proses hand on perawat baru dan preseptorsip. Perancanaan pelaksanaan kredensial seluruh perawat sehingga menjamin ketersedian tenaga keperawatan sesuai dengan kewenangan klinis. Perencanaan bidang keperawatan dibuat sesuai dengan visi dan misi, filosofi, kebijakan, prosedur, peraturan serta perencanaan strategis organisasi. Christina (2019).

Discharge planning menurut National Council of Social Service (NCSS) adalah suatu rencana pulang pada pasien yang merupakan bagian dari perencanaan perawatan pasien dan bertujuan untuk memberdayakan dan memaksimalkan potensi pasien untuk hidup secara mandiri melalui dukungan-dukungan dan sumber- sumber yang ada dalam keluarga dan masyarakat. Discharge planning sangat diperlukan dalam memberikan asuhan keperawatan kepada klien di rumah sakit, sehingga perlu dipersiapkan oleh perawat dan dilakukan sedini mungkin. Discharge planning yang dilakukan secara dini akan memberikan dampak terhadap lamanya perawatan pasien di rumah sakit, mengurangi biaya perawatan, menurunkan angka kekambuhan, dan memungkinkan intervensi rencana pulang dilakukan dengan tepat waktu. Suprapti (2017)

Dalam memberikan asuhan keperawatan, perawat harus memiliki kemampuan dalam melakukan perencanaan dan pelaksanaan asuhan keperawatan secara berkesinambungan. Kemudian melakukan evaluasi dan mengkaji ulang perencanaan perawatan dengan pasien. Perawat juga harus mampu meninjau secara kritis program hemodialisis pasien, berpartisipasi dalam pengembangan kualitas, dan memiliki kemampuan dalam menggunakan peralatan yang berhubungan dengan hemodialisis. Selain itu, agar dapat memberikan asuhan keperawatan yang berkualitas dan keselamatan pasien terjamin, maka perawat juga harus memiliki pengetahuan mengenai pendokumentasi asuhan keperawatan, mengetahui tentang dosis kecukupan dialisis pada pasien, menjamin bahwa keinginan dan kebutuhan pasien menjadi prioritas.

\section{Syarat-syarat perencanaan pelayanan kesehatan}

Pada umumnya perencanaan yang baik berisikan atau memuat 6 unsur yaitu what, where, when, who, why dan how. Dibawah ini akan dijelaskan keenam unsur tersebut. Arina (2020) 


\section{Tindakan yang harus dikerjakan (what)}

menguraikan kegiatan-kegiatan pelayanan kesehatan yang akan dilaksanakan serta faktor-faktor pendukung yang diperlukan untuk melaksanakan kegiatan-kegiatan tersebut agar pelayanan kesehatan yang menjadi tujuan dapat dihasilkan.

2. Penyebab tindakan tersebut harus dilaksanakan (why)

Alasan suatu kegiatan harus dikerjakan dan tujuan yang harus dicapai. Contoh program imunisasi sebagai program pemerintah untuk mengurangi angka kematian dan kesakitan bayi dan anak.

3. Tempat tindakan tersebut harus dilaksanakan (where)

lokasi fisik setiap kegiatan yang harus dikerjakan sehingga tersedia segala fasilitas-fasilitas yang dibutuhkan untuk mengerjakan program tersebut. Contoh oh tindakan imunisasi dapat dilaksanakan di puskesmas.

4. Waktu yang tepat untuk melaksanakan tindakan (when)

menguraikan waktu dimulainya pekerjaan dan diselesaikannya pekerjaan baik untuk tiap-tiap bagian pekerjaan maupun untuk seluruh pekerjaan.contoh kegiatan imunisasi dan menimbang berat badan balita dapat dilakukan secara sistematis.

5. Subjek yang akan melakukan tindakan (who)

Menguraikan para petugas yang akan mengerjakan pekerjaan baik mengenai kuantitas maupun kualitas, seperti kualifikasi pegawai (keahlian, pengalaman), wewenang dan tanggung jawab dari masing-masing pegawai. contoh petugas imunisasi penyuluhan $\mathrm{KB}$

6. Langkah-langkah untuk melaksanakan tindakan (how)

Menguraikan tindakan untuk mengefektifkan aktifkan waktu dan biaya.

Perencanaan sebagai upaya memutuskan apa yang akan dilakukan, siapa yang melakukan, bagaimana, kapan dan dimana hal tersebut akan dilakukan. Perencanaan 
adalah suatu proses memulai dengan sasaran, batasan strategi, kebijakan dan rencana detail untuk mencapainya. Christina (2019).

Proses asuhan keperawatan merupakan tugas dan kewajiban seorang perawat dari pasien datang sampai pasien pulang, dimulai dengan pengkajian secara menyeluruh, kemudian menegakkan diagnosa keperawatan dari data pengkajian tersebut, serta melaksanakan intervensi, implementasi dan evaluasi keefektifan diagnosa awal yang sudah ditegakkan.

Pendokumentasian asuhan keperawatan adalah proses pelaksanaan pencatatan asuhan keperawatan yakni dari pengkajian saat masuk sampai pasien dinyatakan sehat. Diagnosis yang diangkatberdasarkan masalah yang ditemukan, perencanaan keperawatan, tindakan yang dilakukan serta evaluasi dari proses asuhan keperawatan yang diberikan.

Pendokumentasian perencanaan asuhan keperawatanpada aspek tindakan yang direncanakan jarang dilakukan. Pendokumentasian pada tindakan, dimana yang paling jarang dilakukan yakni merevisi tindakan berdasarkan hasil evaluasi, serta pendokumentasian evaluasi yang paling jarang adalah hasil evaluasi dicatat pada setiap shiftnya.

Tujuan perencanaan adalah untuk membuat keputusan yang baik mengenai halhal yang perlu dilaksanakan dan cara melaksanakannya. Dengan perencanaan dapat disediakan arah yang perlu ditempuh dalam pencapaian tujuan teknik perencanaan juga memungkinkan adanya kontrol yang efektif karena dengan perencanaan, pelaksanaan dapat menyusun standar yang dapat dijadikan petunjuk dalam penilaian aktivitas.

Perencanaan dimulai dengan identifikasi tujuan. Tujuan terdiri dari tujuan umum (goal) dan sasaran (objective). Tujuan umum adalah pernyataan suatu keinginan yang merupakan fraksi dari misi atau tujuan unit kerja atau organisasi perusahaan.

Perencanaan mengungkapkan cara untuk mencapai tujuan. Perencanaan mencakup pencapaian tujuan umum di dalam sasaran yang lebih spesifik dan penjabaran sasaran itu ke dalam kegiatan yang harus dilaksanakan untuk mencapainya. 
Perencanaan juga mencakup penentuan mengenai sumber daya yang diperlukan untuk mencapai tujuan.

\section{Manfaat dan keuntungan perencanaan pelayanan kesehatan.}

Manfaat yang diperoleh oleh staf dan pimpinan biro organisasi memiliki sebuah perencanaan, yaitu:

1.Mengetahui tujuan yang ingin dicapai organisasi dan cara mencapainya.

2. Mengetahui jenis dan struktur organisasi yang dibutuhkan.

3. Mengetahui jenis dan jumlah staf yang diinginkan komandan uraian tugasnya.

4. Mengetahui sejauh mana efektivitas kepemimpinan dan pengarahan yang diperlukan.

5. Mengetahui bentuk dan standar pengawasan yang akan dilakukan.

\section{Penutup}

Asuhan keperawatan adalah kerangka kerja dan struktur organisasi yang kreatif untuk memberikan pelayanan keperawaan, namun asuhan keperawatan juga cukup fleksibel untuk digunakan disemua lingkup keperwatan. Perencanaan sebagai upaya memutuskan apa yang akan dilakukan, siapa yang melakukan, bagaimana, kapan dan dimana hal tersebut akan dilakukan. Perencanaan adalah suatu proses memulai dengan sasaran, batasan strategi, kebijakan dan rencana detail untuk mencapainya.

\section{Daftar pustaka}

1. Ariga R A. 2020. Buku ajar implementasi manajemen pelayanan kesehatan dalam keperawatan. Deepublish : Yogyakarta.

2. Asmadi. 2008. Konsep dasar keperawatan. Penerbit buku kedokteran EGC: Jakarta

3. Zendrato M V, Rr.Tutik S H. 2017. Optimalisasi pengelolaan asuhan keperawatan di instalasi rawat jalan rumah sakit X. JPPNI Vol.02/No.02
4. Butar-Butar,
J.,
\&Simamora,
$\mathrm{R}$.
$\mathrm{H}$.
(2016).
HubunganMutuPelayananKeperawatandengan Tingkat KepuasanPasienRawatInap di RSUD PandanKabupatenTapanuli Tengah. JurnalNers Indonesia, 6(1), 50-63. 
5. Simamora,

$\mathrm{R}$.

$\mathrm{H}$.

(2005). HubunganPersepsiPerawatPelaksanaTerhadapPenerapanFungsiPengorganisa sian Yang DilakukanOlehKepalaRuanganDenganKinerjanyaDiruangRawatInap RSUD Koja Jakarta Utara (Doctoral dissertation, Tesis FIK UI, Tidakdipublikasikan).

6. Ermayani M, Aprilia N. 2017. Pengembangan format dokumentasi asuhan keperawatan berbasis standardized nursing language (SNL) nanda-i, Noc dan Nic di ruang rawat inap. Mahakam Nursing Journal Vol 2, No. 2.

7. Christina P, dkk. 2019. Analisis ketidaksinambungan dokumentasi perencanaan asuhan keperawatan: metode Ishikawa. Jurnal Ilmiah Kesehatan (JIK) Vol XII, No II,

8. Wulandini P, dkk. 2016. Faktor-faktor yang berhubungan dengan pendokumentasian asuhan keperawatan di rumah sakit jiwa.NERS JURNAL KEPERAWATAN,Volume 12, No.2

9. Depkes RI, 2006, Intrumen evaluasi penerapan standar asuhan keperawatan di rumah sakit,Jakarta.

10. Wijaya C P. 2016. Pengaruh burnoust syndrome terhadap proses asuhan keperawatan (studi pada perawat rumah sakit Medika utama Blitar). JURNAL REVITALISASI Jurnal Ilmu Manajemen Vol. 5, Nomor 3.

11. Suprapti E. 2017. Pengaruh discharge planning terstruktur untuk meningkatkan kesiapan pasien TB paru menghadapi pemulangan (studi eksperimental di RSUD Tugurejo dan RSUD kota Semarang).Jurnal Ilmu Keperawatan dan Kebidanan (JIKK), Vol. III No.1.

12. Hermalia I, dkk. 2019. Potensi perawat hemodialisis. Jurnal Keperawatan Komprehensif Vol. 5 No. 2. 